\title{
INSIDER TRADING: THE ISSUER'S DISPOSITION OF AN ALLEGED 16 (b) VIOLATION
}

\author{
When corporate officers are apprised of possible 16(b) liability on \\ the part of a fellow insider, an appropriate reaction by them en- \\ compasses both practical and legal considerations. In this comment \\ non-legal factors influencing managerial judgments are related to \\ precepts applied by courts in resolution of $16(b)$ claims. $A$ detailed \\ investigation is made into the status of the common law Business \\ Judgment Rule in the context of insider trading.
}

$\mathrm{S}_{\text {ection }} 16(\mathrm{~b})$ of the Securities Exchange Act of $1934^{1}$ provides that, for the purpose of deterring unfair use of insider information, the profit realized by an "insider"2 from a "purchase and sale" or a "sale and purchase" of any non-exempt equity security of a corporation within a period of less than six months is recoverable by the corporation issuing the security. ${ }^{3}$ The statute does not pro-

115 U.S.C. $\$ 78 \mathrm{p}(\mathrm{b})(1964)$ [hereinafter cited as $\$ 16(\mathrm{~b})]$.

2 Section 16 (a) of the Exchange Act, 15 U.S.C. $\$ 78 \mathrm{p}$ (a) (1964), provides that cvery officer and director of a corporation required to register under the 1934 Act and cvery person "who is directly or indirectly the beneficial owner of more than 10 per centum of any class of any equity security" of such corporation is required to file with the SEC (and if the security is registered on a national securities exchange, also with the exchange) a statement of the amount of all equity securities of the issuer of which he is the beneficial owner. After the initial statement, if any changes occur in the beneficial ownership of a particular officer, director, or ten percent shareholder during a particular calendar month, the "insider" involved must file, within ten days after the close of the month, a statement detailing the changes and showing the amount of each equity security of the corporation beneficially owned at the end of the month. In addition to making the reports available to the Commission and the appropriate exchanges, the SEC in a monthly Official Summary of Security Transactions and Holdings compiles and publishes the information contained in the reports. These pamphlets are widely distributed and are available at the regional offices of the Commission and at every exchange. 2 L. Loss, Securities Regulation 1039 n.9 (2d ed. 1961) [hereinafter cited as Loss].

Failure to file reports as required by $\$ 16$ (a) not only tolls the statute of limitations, see note 46 infra, but also exposes the insider to the sanctions of criminal prosecution, see, e.g., United States v. Guterma, 281 F.2d 742, 752-53 (2d Cir.), cert. denied, 364 U.S. 871 (1960), and mandatory injunction, see, e.g., SEC v. Great Am. Indus., Inc., CCH FED. SEC. L. REP. I 91,819 (S.D.N.Y. 1966). The insider will not, however, incur civil liability as there is no right of private action for damages under $\$ 16$ (a). See, e.g., Robbins v. Banner Indus., Inc., CCH FED. SEC. L. REP. ๆ 91,861 (S.D.N.Y. 1966). Contra, Kroese v. Crawford, [1961-1964 Transfer Binder] CCH FED. SEC. L. REP. I 91,262 (S.D.N.Y. 1963).

${ }^{3}$ Section $16(\mathrm{~b})$ specifies that no suit may be brought more than two years after the profit sought to be recovered was realized. See note 31 infra. The section is designed to prevent the profitable use of information, not available to the investing public, obtained by insiders for their personal advantage by virtue of their position. 
hibit insider short-swing trading but only makes the profit from any short-term transactions by an insider recoverable by the corporation. Suit for recovery may be brought by the issuer or, upon its refusal to institute the proceeding or failure diligently to prosecute the action, by any owner of an equity security of the issuer. ${ }^{4}$ Nevertheless, recovery inures to the corporation whether it or the security holder institutes the action. The purpose of this comment is to examine the factors usually considered by corporate officials and counsel before charting a course of action when a $16(\mathrm{~b})$ violation or possible violation has come to their attention. Particular attention will be given the issue of whether corporate officers' failure to pursue a 16 (b) claim may amount to a breach of a common law fiduciary duty. In many situations a corporation will disfavor insider speculative trading in its securities because of the danger that corporation policies may be perverted by insiders in order to create market conditions favorable to rapid trading. ${ }^{5}$ Nevertheless, the issuer's management upon notification of possible insider liability may be reluctant to institute a section $16(\mathrm{~b})$ proceeding, for some applications of section 16 (b), as enacted by Congress and developed by the courts, have

S. REP. No. 1455, 73d Cong., 2d Sess. 55 (1934), states: "Among the most vicious practices unearthed at the hearings before the subcommittee was the flagrant betrayal of their fiduciary duties by directors and officers of corporations who used their positions of trust and the confidential information which came to them in such positions, to aid them in their market activities. Closely allied to this type of abuse was the unscrupulous employment of inside information by large stockholders who, while not officers and directors, exercised sufficient control over the destinies of their companies to enable them to acquire and profit by information not available to others."

Prior to the enactment of the Exchange Act, insiders' profits arising out of speculation in securities of their own companies were accepted as a usual emolument, and insiders were relatively free to trade in these securities. For a discussion of the common law liability of insiders see Conant, Duties of Disclosure of Corporate Insiders Who Purchase Shares, 46 CORNELl L.Q. 53, 53-66 (1960), and Yourd, Trading in Securities by Directors, Officers and Stockholders: Section 16 of the Securities Exchange Act, 38 MICH. L. REv. 133, 139-43 (1939).

s "Suit to recover such profit may be instituted at law or in equity in any court of competent jurisdiction by the issuer, or by the owner of any security of the issuer in the name and in behalf of the issuer if the issuer shall fail or refuse to bring such suit within sixty days after request or shall fail diligently to prosecute the same thereafter . . ." 15 U.S.C. $\$ 78 p$ (b) (1964). See note 31 supra.

$\checkmark$ The greatest danger of insider speculation, however, may be the deterrent effect insider trading has on the willingness of the general investing public to invest in any security the price of which may not represent true value. Congressional recognition of the deleterious effect on the investing public is illustrated by a committee report stating that 'investors' confidence in the exchange markets can be effected only by a clearer recognition upon the part of the corporate managers of companies whose securities are publicly held of their responsibilities as trustees for their corporations." H.R, REP. No, 1383, 73d Cong., 2d Sess. 13 (1934). 
perpetrated inequities on "innocent" insiders, that is, those who have acted in complete good faith. ${ }^{6}$ A cursory examination of the operation of section 16 (b) will illustrate its arbitrary nature which may discourage the corporate officers from taking action against a fellow insider. For example, an insider who holds his security for six months or more before selling is not subject to liability ${ }^{7}$ under section 16(b), notwithstanding proof that he has taken advantage of inside information to realize profits on the transactions. ${ }^{8}$ Similarly, the insider will not incur 16 (b) liability-and the issuer will not be able to recover the profits realized-on transactions initiated by relatives or friends ${ }^{9}$ who utilize confidential information disclosed by the insider.10 The provision also does not permit recovery from a "guilty" insider in cases involving only purchases or sales within the statutory holding period.11

The subject of the inequities perpertrated by $\S 16(\mathrm{~b})$ and possible alternative approaches to the problem of insider trading has been treated extensively by the commentators. See, e.g., Munter, Section 16(b) of the Securities Exchange Act of 1934: An Alternative to "Burning Down the Barn in Order to Kill the Rats," 52 CoRnelL L.Q. 69 (1966); Painter, The Evolving Role of Section 16(b), 62 Mick. L. REv. 649 (1964).

Thether a holding period limited to six months imposes a substantial hardship or curb on insiders is questionable, particularly since the tax laws already encourage a holding period of six months in order to obtain long-term capital gains treatment. INT. Rev. CODE of 1954, §§ 1222 (3), 1201 (b); see Adler v. Klawans, 267 F.2d 840, 845 (2d Cir. 1959). Nonetheless, since congressional hearings revealed that abuses of inside information generally occurred within a short term, the six months time limit was deemed adequate to eliminate most of the abuse and necessary to distinguish between "legitimate" long-term investment and "illegitimate" short-swing speculation. S. REP. No. 792, 73d Cong., 2d Sess. 9 (1934); see Hardee, Stock Options and the "Insider Trading" Provisions of the Securities Exchange Act, 65 HARv. L. REv. 997, 1007 (1952); Comment, The Scope of "Purchase and Sale" Under Section 16(b) of the Exchange Act, 59 YaLE L.J. 510, 511 (1950).

8 "One can speculate on whether the moral or ethical values are altered by the passage of 24 hours but the statute makes an honest if not honorable man out of the insider in that period." Adler v. Klawans, 267 F.2d 840, 845 (2d Cir. 1959).

${ }^{\circ}$ Transactions by officials of different corporations, with whom the insider may have an informal reciprocal agreement to exchange inside information about cacl other's corporations, are not subject to the provision. 2 Loss 1043.

10 Early drafts of $\$ 16$ (b) provided that disclosure of inside information by insiders was unlawful and that the issuer could recover the profits realized by one to whom inside information had been divulged unless the insider's confidant had no reasonable ground to bclieve that disclosure was improper. H.R. 7852, 73d Cong., 2d Sess. (1934); S. 2693, 73d Cong., 2d Sess. $\S 15 b$ (1934). These provisions were deleted from the final draft "presumably because the burden of proof made enforeement unfeasible." Smolowe v. Delendo Corp., 136 F.2d 231, 236 (2d Cir.), cert. denied, 320 U.S. 751 (1943).

II Liability for single transactions may, however, arise under the common law duty of disclosure, see articles cited note 3 supra, or the prohibition of provisions of the securities acts other than $\$ 16$ (b) of the Exchange Act, see Munter, supra note 6, at 72 .

Professor Loss apparently feels that an insider could be liable under Rule 10b.5 to one from whom he has purchased stock without revealing material information 
Section 16 (b) often imposes liability on the "innocent" insider who has not abused his position since the actual unfair use of confidential information by insiders or the intent to profit by its use is irrelevant to the question of liability under section $16(\mathrm{~b}) .^{12}$ In addition, the courts, perhaps disenchanted with the limitations on the operation of section $16(\mathrm{~b})$, have given expansive interpretations to its provisions. As a result of this judicial reaction it is possible to envision imposition of 16 (b) liability and the recovery of profits from an insider in the following circumstances: first, neither has he taken advantage of confidential information nor has he been in a position to utilize such information; ${ }^{13}$ second, he has in fact suffered

and to the corporation under $\$ 16(\mathrm{~b}) .3$ Loss 1473-74. For arguments supporting double recovery see Comment, The Prospects for Rule X-10B-5: An Emerging Remedy for Defrauded Investors, 59 YALE L.J. 1120, 1140-42 (1950).

${ }^{12}$ See, e.g., Petteys v. Blau, 367 F.2d 528 (8th Cir. 1966), cert. denied, 385 U.S. 1006 (1967); Smolowe v. Delendo Corp., 136 F.2d 231 (2d Cir.), cert. denied, 320 U.S. 751 (1943). Thus, the insider may not defend his short-swing trading by submitting evidence of the details of the transactions to show that he did not possess any inside information. Justification for the objective nature of the operation of $\S 16(\mathrm{~b})$ was offered by one of its draftsmen as follows: "You hold the director, irrespective of any intention or expectations to sell the security within 6 months after, because it will be absolutely impossible to prove the existence of such intention or expectation, and you have to have this crude rule of thumb, because you cannot undertake the burden of having to prove that the director intended, at the time he bought, to get out on a short swing." Hearings on Stock Exchange Practices Before the Senate Comm. on Banking and Currency, 73d Cong., 1st Sess., pt. 15, at 6557 (1934) (testimony of Thomas G. Corcoran).

${ }^{13}$ Although $\S 16$ (b) applies to every transaction that might afford an opportunity for insider abuse, there is some doubt as to the applicability of the section to a factual situation in which unfair speculation is impossible. The section was originally interpreted in the Second Circuit to apply to anl stock conversions followed or preceded by a sale or purchase within six months of the conversion. Park \& Tilford, Inc. v. Schulte, 160 F.2d 984 (2d Cir.), cert. denied, 332 U.S. 761 (1947). This per se approach has since been rejected by the same circuit: "[I]n deciding whether a certain transaction is a Section 16 (b) 'purchase' or 'sale' it is relevant to first consider whether the transaction in any way makes possible the unfair insider trading that Section $16(\mathrm{~b})$ was designed to prevent." Blau v. Lamb, 363 F.2d 507, 518 (2d Cir. 1966), cert. denied, 385 U.S. 1002 (1967). The Third Circuit, on the other hand, has concluded that "[s]ection 16 (b) does set up a 'rule of thumb' and was intended by Congress to do precisely that." Heli-Coil Corp. v. Webster, 352 F.2d 156, 166 (3d Cir. 1965). However, as noted in a recent Eighth Circuit opinion, the objective approach to $\$ 16(\mathrm{~b})$ problems adopted by Heli-Coil "is founded almost solely upon the rationale of Park \& Tilford. Since Park of Tilford has now been severely limited by the later Second Circuit decisions on this issue, we cannot refrain from the belief that Heli-Coil is likewise weakened." Petteys v. Blau, 367 F.2d 528, 535 (8th Cir. 1966), cert. denied, 385 U.S. 1006 (1967). The objective approach in this area is further shaken by the conclusion of the Securities and Exchange Commission that the conversion of equity securities is not even comprehended within the purposes of $\$ 16(\mathrm{~b})$. Securities Exchange Act Release No. 7826 (Feb. 17, 1966), amending Rule 16b-9, 17 C.F.R. $\$ 240.16 \mathrm{~b}-9$ (1967). Today the evolving subjective standard is gaining acceptance at a rapid pace, but not without dissent from some of the commentators. See, e.g., Kramer, An Examination 
an overall economic loss on the group of transactions comprising the 16 (b) violation; ${ }^{14}$ third, he has had little reason to suspect that the transactions would fall within the scope of the purchase and sale requirement; ${ }^{15}$ and finally, he has been encouraged to enter into the transaction by the issuer, and, in fact, it has benefited from his insider trading. ${ }^{16}$

of Section 16(b), 21 Bus. LAwYER 183, 186 (1965): "My thesis for today is that recent decisions under Section 16 (b) have tended to move away radically, and I think wrongly, from the certainty which appears to have been intended in the drafting of the statute . ..."

16 In Smolowe v. Delendo Corp., 136 F.2d 231 (2d Cir.), cert. denied, 320 U.S. 751 (1943), the Second Circuit laid down the method for computing the profits realized: "The statute is broadly remedial .... We must suppose that the statute was intended to be thorough-going, to squeeze all possible profits out of stock transactions, and thus to estabhish a standard so high as to prevent any confiict between the selfish interest of a fiduciary officer, director, or stockholder and the faithful performance of his duty .... The only rule where all possible profits can be surely recovered is that of lowest price in, highest price out-within six months ... ." Id. at 239. Thus, profit is calculated by first subtracting the lowest purchase price from the highest sale price of an equal number of shares within the six months period. Then the next lowest purchase price is subtracted from the next highest sale, and the process is repeated until all of the shares purchased during the period for which recovery of profits is sought have been subtracted from shares sold for higher prices during the same period. See Rubin \& Feldman, Statutory Inhibitions upon Unfair Use of Corporate Information by Insiders, $95 \mathrm{U}$. P.. L. REv. 468, $482-83$ (1947). Since losses suffered may not be offset against profits, in a particular case the insider may be liable for "profits" in an amount greater than his actual gain. See, e.g., Gratz v. Claughton, 187 F.2d 46 (2d Cir.), cert. denied, 341 U.S. 920 (1951) ( $\$ 300,000$ judgment rendered against ten percent shareholder whose trading had resulted in an actual loss of over $\$ 400,000)$. In fact, the issuer may recover "profits" from an insider who has suffered a loss on each transaction during the six-month period. See Munter, supra note 6, at 82.

${ }^{15}$ No definition of "purchase and sale" or "sale and purchase" can be found in $\$ 16(\mathrm{~b})$. Another provision of the Act defines "purchase" simply as "any contract to buy, purchase, or otherwise acquire." Securities Exchange Act $\$ 3$ (a) (13), 15 U.S.C. $\$ 78$ (c) (a) (13) (1964).

Ignorance or misunderstanding by insiders of $\$ 16$ (b) will not, of course, provide them with a defense before the courts. Munter, supra note 6, at 89 . However, the corporation's decision whether to seek to recover the profits may be affected by the insider's good faith belief that the section would not apply to his situation.

${ }^{26}$ Insider trading may benefit the corporation in several respects. A recent report by the New York Stock Exchange has disclosed that stockholders want their officers and directors to have a substantial amount of their own capital invested in the enterprise. New York Stock Exchange, The Corporate Director and the Investing Publtc (1965), cited in Munter, supra note 6, at 88 n.82. Indeed, management may initiate employee stock purchase or stock option plans to provide additional incentives for insiders to improve their performance. The recent SEC v. Texas Gulf Sulphur Co., 258 F. Supp. 262 (S.D.N.Y. 1966), decision recognized that nothing in the Act "precludes insiders from purchasing stock of their company or from being beneficiaries of the company's incentive stock option plan. On the contrary, it is important under our free enterprise system that insiders, including directors, officers, and employees, be encouraged to own securities of their company. The incentive that comes with stock ownership benefits both the company and its shareholders." Id. at 280 . Of course, 
Considerations InfLuencing Initiation of aN IsSUER's

\section{SECTION 16(b) SuIT}

\section{Tactical Matters}

Certainty of Liability. When the possibility that an insider has incurred liability under section $16(\mathrm{~b})$ is brought to the attention of a corporation, three alternative avenues will be open to management:

(a) do nothing;

(b) attempt to induce the insider voluntarily to surrender the profits to the issuer or to compromise with the issuer; or

(c) bring suit against the insider to recover the profits.

Frequently the procedure to be followed will be influenced by the certainty of liability. For example, in situations where insider liability is clear, a substantial likelihood exists that the directors will incur personal liability for breach of fiduciary duty if they fail to settle the claim or institute suit. Further, if the insider is definitely answerable under section $16(\mathrm{~b})$, a shareholder of the corporation will likely institute suit in the absence of an initiation of litigation by management.17. On the other hand, if liability is unsettled the corporation will probably have no legal duty to initiate an action, and its failure to respond will not sustain a charge of fiduciary breach. ${ }^{18}$

$\$ 16$ (b) does not preclude insider ownership, but only discourages both a purchase and sale within a relatively short period of time.

The argument also has been made that insider trading benefits the corporation in retarding undue declines and rises in the market. Munter, supra note 6 , at 88 . However, there are persuasive arguments that, even assuming insiders will trade against the market, no stabilizing effect resuits from such trading, see Rubin \& Feldman, supra note 14, at 501.02, and that even if market trends are modified, violation of the insider's fiduciary duty is not justified, see 2 Loss 1088-89. In any case, it is well established that the corporation, which is often merely the unwilling instrument for enforcement of the statutory policy, will not be estopped from suing the insider. See, e.g., Magida v. Continental Can Co., 231 F.2d 843 (2d Cir.), cert. denied, 351 U.S. 972 (1956) (stock was sold at the issuer's suggestion and with the approval of a majority of shareholders); Perfect Photo, Inc. v. Grabb, 205 F. Supp. 569 (E.D. Pa. 1962) (sole shareholder of the corporation agreed to finance defendant's purchase); Perlman v. Timberlake, 172 F. Supp. 246 (S.D.N.Y. 1959) (corporation approved the transaction); Blau v. Allen, 163 F. Supp. 702 (S.D.N.Y. 1958) (insider desired to benefit the corporation); Jefferson Lake Sulphur Co. v. Walet, 104 F. Supp. 20 (E.D. La. 1952), aff'd, 202 F.2d 433 (5th Cir.), cert. denied, 346 U.S. 820 (1953) (stock acquired pursuant to a stock option plan). Contra, Consolidated Eng'r Corp. v. Nesbit, 102 F. Supp. 112 (S.D. Cal. 1951), rev'd sub nom. on other grounds Pellegrino v. Nesbit, 203 F.2d 463 (9th Cir. 1953).

${ }^{17}$ See note 4 supra and note 31 infra; of. Cary, Book Review, 75 HaRv. L. Rev. 857, 861 (1962).

${ }^{18}$ See notes 54-61 infra and accompanying text; cf. Truncale v. Universal Pictures Co., 76 F. Supp. 465 (S.D.N.Y. 1948). 
In the corporation's determination of whether to undertake suit, the size of the possible recovery should be considered along with the relative certainty of liability. If a large sum is involved, it is more probable that a security holder will bring the action if the corporation fails to act even though liability is less than certain. On the other hand, where liability is certain but only for a small amount, it would appear that the insider would repay voluntarily the profits to the issuer to avoid the expense and adverse publicity of litigation.19 Upon the failure of corporate officials to press a claim for recovery of a small sum, the likelihood is diminished that the security holder and his attorney will view recovery of an insubstantial sum sufficient inducement to institute an action on behalf of the corporation.

Extrajudicial settlement may, of course, be a desirable alternative to actual litigation by the corporation: not only is adverse publicity avoided, but in addition overall expenditures of time and assets may be reduced. ${ }^{20}$ However, compromises between an insider and the

${ }^{10} \mathrm{It}$ is doubtful in many states whether the corporation will be able to indemnify the insider for his litigation expense. See, e.g., CAL. CoRp. CODE $\S 830$ (West Supp. 1966).

${ }^{20}$ The favorable tax treatment afforded any sum surrendered voluntarily may encourage the insider to settle the claim without suit by either the corporation or a shareholder. A 1951 Tax Court decision refused to permit an insider to deduct the $\$ 16$ (b) "profit" he had disgorged to the corporation. William F. Davis, 17 T.C. 549 (1951). The court viewed the sanction imposed by $\$ 16(\mathrm{~b})$ in the nature of a penalty and reasoned that allowance of a deduction as a business expense or loss would frustrate the policy expressed in the statute. Id. at 556. However, in a later case in which the insider "voluntarily" paid his "profits" to the corporation, without admitting liability, in order to avoid the expenses of litigation and preserve his business reputation, the court allowed the deduction. Laurence W. Marks, 27 T.C. 464 (1956). The court reasoned, first, that the payment was an ordinary and necessary business expense and, second, that allowance of such a deduction where actual liability was highly uncertain would not frustrate "sharply defined public policy" or tend to encourage further violations. Id. at 468 .

This decision was followed by Rev. Rul. 61-115, 1961-1 Cum. BulL. 46, which, in overruling 1.T. 4069, 1952-1 CuM. BuLL. 28, stated that: "The purpose of the statutc is to place the insider in the same position he would have occupied if he had never engaged in the stock dealings. This purpose is not frustrated by the allowance of a tax deduction for amounts paid by reason of section 16 (b); but, rather, the allowance of the deduction is consistent with the purpose of the statute in returning the insider to his original position. ... The income tax significance of the capital stock dealings giving rise to the payment determines whether it is deductible as an ordinary loss or a capital loss." 1961-1 CuM. Burc. at 48.

The rationale of the Marks case would not seem to support the conclusion that deductions as business expenses will be allowed for "amounts paid by reason of section 16 (b)" in all cases. Thus, where payment, although "voluntary," is for the purpose of avoiding liability or payment follows judicial determination of liability the requisite business purpose would be absent. For example, in a recent Tax Court 
issuer must be consummated at arm's length. ${ }^{21}$ Although the insider receives credit for the amount paid, the settlement is no defense to later action by a security holder against the trader..$^{22}$ Moreover, any settlement of a 16 (b) case reached after a security holder has either initiated or intervened in actual litigation will be subject to the provisions of Rule 23 (c) of the Federal Rules of Civil Procedure regulating the procedure for settling class actions. ${ }^{23}$

Position of the Insider in the Corporate Structure. If the insider is sufficiently influential in the corporate hierarchy, the decision of whether to litigate a recovery will not, of course, be totally objective. Since the 1964 amendments to the Securities Exchange Act have extended application of section $16(\mathrm{~b})$ to some corporations whose securities are traded over the counter, ${ }^{24}$ more close corporations, ${ }^{25}$ having one or a few controlling shareholders (who generally will also be directors), fall under the coverage of section $16(\mathrm{~b})$. Such corporations provide a prolific source of inadvertent insider shortswing trading, for often they do not have house counsel and their officials are unfamiliar with the provisions of section $16(\mathrm{~b})$ and especially with the broad definitions of "purchase," "sale," and "profits."28

case the Commissioner argued that the taxpayer's payment to the corporation was motivated by a desire to escape criminal prosecution for violation of the Securities Act and therefore should be a nondeductible personal expense. Joseph P. Pike, 44 T.C. 787 (1965). The court, however, accepted the taxpayer's testimony that payment in satisfaction of a claim of uncertain validity was to preserve his professional reputation, and cited the Marks case in permitting the deduction under $\S 162$ (a) of the Code as a business expense. Id. at 799. Moreover, insiders' attempts to deduct payments as business losses after judicial determination of liability may run afoul of the public policy rationale of the earlier decisions. Allowance of deductions where liability is established may encourage future violations of the section and thus frustrate public policy.

21 See Blau v. Hodgkinson, 100 F. Supp. 361, 371 (S.D.N.Y. 1951); accord, Pappas v. Moss, CCH FED. SEC. L. REP. \91,694 (D.N.J. 1966).

${ }^{22}$ Blau v. Hodgkinson, 100 F. Supp. 361 (S.D.N.Y. 1951).

${ }^{23} \mathrm{~A}$ corporation on its own motion has been permitted to intervene as a plaintiff to insure vigorous prosecution of a $16(\mathrm{~b})$ action where it has reason to fear that the security holder who instituted suit was not diligently pressing the claim. Silverman v. Re, 194 F. Supp. 540 (S.D.N.Y. 1961). In one instance a district court granted a corporation's motion to be made a party plaintiff in order to guard against the dilution of any recovery through the intervention of other shareholders. Gratz v. Claughton, Givil No. 35-410 (S.D.N.Y.), cited in Silverman v. Re, supra at 542 n.4.

24 Securities Exchange Act of $1934 \$ 12(\mathrm{~g}), 15$ U.S.C. $\$ 78 l(\mathrm{~g})$ (1964).

st "Close" is used in this context to indicate that although ownership of shares may not be limited to only a few persons, control of the corporation is firmly vested in the hands of one dominant shareholder or a small group of prominent shareholders. See generally 1 F. O'NEaL, Close Corporations $\$ \S 1.02-.04$ (1958).

so See note 15 supra. 
The insider who is influential within the corporate structure will probably attract greater empathy and elicit more support than one occupying a subordinate managerial position. This emotional factor is usually cloaked by businessmen in the traditional assertion that intracorporate harmony will be jeopardized if management fails to support one of its own number. ${ }^{27}$ However, the weight to be afforded intracorporate harmony would appear to vary inversely with the lack of good faith on the part of the insider. Similarly, the issuer will be much more likely to take affirmative action against the insider if he is not closely related to present management. ${ }^{28}$ For example, the insider may be an officer or director who no longer is connected with the corporation, having assumed a new position with a competitor or having been discharged; ${ }^{20}$ or he may be a dissident shareholder who is part of a "take over" attempt. ${ }^{30}$ In these situations the pressing of a 16 (b) claim may provide management an opportunity to subject its opponents to financial disability or to discredit them in some other manner.

Shareholder's Attorney's Fees Reducing the Corporate Recovery. The primary right to institute an action to recover short-swing profits resides in the corporation. However, since the issuer may fail to act diligently to discover the violation, institute suit, or pursue the cause of action against one of its own officers, directors, or influential stockholders, section $16(\mathrm{~b})$ also provides that any security holder of the issuer may bring action on its behalf. ${ }^{31}$ The recovery of

\footnotetext{
27 See note 6 supra and accompanying text.

${ }^{28}$ See, e.g., Varian Associates v. Booth, 224 F. Supp. 225 (D. Mass. 1963), aff'd, 334 F.2d I (1st Cir. 1964), cert. denied, 379 U.S. 961 (1965).

${ }^{20}$ See, e.g., Perfect Photo, Inc. v. Grabb, 205 F. Supp. 569 (E.D. Pa. 1962).

${ }^{30}$ See, e.g., Carr-Consolidated Biscuit Co. v. Moore, 125 F. Supp. 423, 427 (M.D. Pa. 1954) (defendant alleged that the action was a reprisal measure after he had unsuccessfully attempted to oust management).

${ }_{31}$ The security holder may institute the action if the corporation fails or refuses to bring suit within sixty days after a request is made or fails to prosecute diligently any action taken. To permit commencement of suits prior to the end of the sixty day period "not only deprives the corporation of its right to conduct the litigation but also disregards the clear and unequivocal language of the statute." Henss v. Schneider, 132 F. Supp. 60, 62 (S.D.N.Y. 1955). Morcover, to permit such suits "would subject a corporation to harassment by a multiplicity of suits by its security holders, all of whom would be equally entitled to assert the corporate right." Id. at 63 .

The sixty-day waiting period may be waived if any demand that the corporation institute suit would be futile. Thus, no demand was necessary where the individual whose profits were sought to be recovered had effective control over the corpoxation, Grossman v. Young, 72 F. Supp. 375, 380 (S.D.N.Y. 1947); accord, Miller v. General Outdoor Advertising Co., CCH FED. SEC. L. REP. ๆ 91,291 (S.D.N.Y. 1963); Wcisman v. Spector, 158 F. Supp. 789 (S.D.N.Y. 1958); Netter v. Ashland Paper Mills, Inc., 19
} 
attorneys' fees is one of several judicial developments relating to 16 (b) suits which compounds the general negative reaction to such suits by a corporation which has decided not to prosecute the claim. Although the section contains no authorization for compensation or reimbursement of costs to security holders instituting actions, the courts have liberally awarded counsel fees. They have reasoned that reimbursement is required by equitable considerations ${ }^{32}$ and that such fees often provide the "sole stimulus" for vigorous enforcement of the statute. ${ }^{33}$ As a result of the granting of substantial allowances, usually in the form of a percentage of the total recovery from the insider, ${ }^{34}$ the issuer may conclude that the action has been

F.R.D. 529 (S.D.N.Y. 1956); where the insider had close business and family relationships with the board of directors which had not acted although probably having knowledge of the transactions, Kogan v. Schulte, 61 F. Supp. 604, 606 (S.D.N.Y. 1945); or where the issuer in a proxy statement had advised its stockholders that it did not propose to bring suit, Berkwich v. Mencher, 239 F. Supp. 792 (S.D.N.Y. 1965). Similarly, if a delay of sixty days before bringing suit would result in the statute of limitations barring recovery, the full statutory period need not be observed. See, e.g., Grossman v. Young, supra at 380; Henss v. Schneider, supra (dictum).

Rule 24 (a) (2) of the Federal Rules of Civil Procedure provides for intervention whenever representation of the applicant's interest may be inadequate. The courts have been liberal in permitting intervention by security holders to insure that corporate rights would be fully protected whenever it appeared that corporations, in prosecuting suits or appeals, were not acting with diligence. See, e.g., Pellegrino v. Nesbit, 203 F.2d 463 (9th Cir. 1953); Park \& Tilford, Inc. v. Schulte, 160 F.2d 984 (2d Cir.), cert. denied, 332 U.S. 761 (1947); Twentieth Century-Fox Film Corp. v. Jenkins, 7 F.R.D. 197 (S.D.N.Y. 1947).

32 Shareholders lave been reimbursed for their counsel fees, out of the fund recovered by the corporation, by analogy to the rule in stockholders' or creditors' derivative actions. Smolowe v. Delendo Corp., $136 \mathrm{~F} .2 \mathrm{~d}$ 231, 241 (2d Cir.), cert. denied, 320 U.S. 751 (1943). Thus, the corporation which has received the benefit of the attorneys' services, in an action which it had been unwilling to institute, should pay for the reasonable value of those services. Id.

${ }^{33}$ The Securities and Exchange Commission is given no direct power to enforce $\$ 16(b)$, and thus proceedings can be initiated only by the issuer or one of its security holders. The corporation may be unwilling to sue one of its officers, directors or influential shareholders, and the incentive for shareholder action will not be great, as his pro rata recovery, realized by the increase in the corporation's assets, generally will be quite small. Although in certain circumstances a shareholder may be motivated to bring suit as the basis of an attempt to oust management, see Yourd, supra note 3 , at 152 , or a corporation may act as a reprisal measure against an insider, see Carr-Consolidated Biscuit Co. v. Moore, 125 F. Supp. 423, 427 (M.D. Pa. 1954), generally "the possibility of recovering attorney's fees will provide the sole stimulus for the enforcement of 16 (b), [and] the allowance must not be too niggardly." Smolowe v. Delendo Corp., 136 F.2d 231, 241 (2d Cir.), cert. denied, 320 U.S. 751 (1943).

\&4 See 2 Loss 1052, and cases cited therein; Cook \& Feldman, Insider Trading Under the Securities Exchange Act, 66 HARv. L. REv. 385, 421 \& nn.142-43. The amount depends upon the size of the fund recovered, Kors v. United Whelan Corp., CGH FED. SEC. L. REP. I 90,970 (S.D.N.Y. 1960); the time consumed and the difficulty of the litigation, Lewis v. Rosenberg, CCH FED. SEc. L. REP. I 90,856 (S.D.N.Y. 1958); and the contribution made by the attorney, Park \& Tilford, Inc. v. Schulte, 160 F.2d 984 
commenced not for the benefit of the issuer or its shareholders, but primarily to gain a fee for the security holder's attorney. Nevertheless, the courts have refused to consider charges of champerty, ${ }^{36}$ or any other allegations relating to the plaintiff's motive for suing, ${ }^{36}$ as a defense to a claim for an award of attorney's fees. ${ }^{37}$ Moreover,

(2d Cir.), cert. denied, 332 U.S. 761 (1947); Magida v. Continental Can Co., 176 F. Supp. 781, 783 (S.D.N.Y.), affid, 231 F.2d 843 (2d Cir.), cert. denied, 351 U.S. 972 (1956). If a shareholder is permitted to intervene in an action brought by the corpo. ration and does not contribute to the proceedings, compensation will not be awarded. Berkey \& Gay Furniture Co. v. Wigmore, CGH FEd. SEc. L. REP. \90,376 (S.D.N.Y. 1947). Moreover, the shareholder will not be compensated for "watchdog" scrvices designed to insure against improvident settlements after the corporation has instituted suit. Gilson v. Chock Full o'Nuts Corp., 331 F.2d 107 (2d Cir. 1964) (dictum).

${ }^{36}$ In Magida v. Continental Can Co., 176 F. Supp. 781 (S.D.N.Y. 1956), the defendant alleged that, on the basis of the infinitesimal interest of the shareholder in the outcome of the suit (if successful his equity interest in the corporation would have been increased by $\$ 1.10$ ), the proceedings must have been financed by the attorney for the sole purpose of earning a fee. The court recognized the possible existence of a champertous agreement but held that the claims were irrelevant. "Presumably Congress is aware of the opportunity presented to attorneys to finance suits for their benefit, but apparently it regards public policy against proved and repeated violations of fiduciary responsibility by corporate officers at the expense of the public more detrimental to public good than the violation of generally accepted ethics by attorneys. The personal feelings of the court on the subject aside, its duty is to aid in the enforcement of the statute ...." Id. at 783. The Second Circuit affirmed the district court, stating that "the public policy of New York cannot nullify this feclerally created right ...." Magida v. Continenal Can Co., 231 F.2d 843, 818 (2d Cir.), cert. denied, 351 U.S. 972 (1956).

${ }^{36}$ See, e.g., Blau v. Ogsbury, CCH FED. SEc. L. REP. ๆ 90,635 (S.D.N.Y. 1953), aff'd on other grounds, 210 F.2d 426 (2d Cir. 1954) (motive immaterial even though shares purchased after the transaction of which plaintiff complains); Magida v. Continental Can Co., 12 F.R.D. 74 (S.D.N.Y. 1951) (denial of motion to compel plaintiff to answer questions relating to motive. But cf. Magida v. Continental Can Co., 12 F.R.D. 400, 402 (S.D.N.Y. 1952) (plaintiff's motion for summary judgment denied in part because circumstances under which he acquired his shares might call for application of the doctrine of "unclean hands").

${ }^{37}$ The champerty problem created by the present mode of enforcement has troubled courts and commentators. The Second Circuit has affirmed the position taken by a lower court that although the statute may promote the "violation of generally accepted ethics by attorneys. . . . [i]t is for the Congress, if it sees fit, to curb the evil side effects of the statute by imposing appropriate restrictions." Magida v. Continental Can Co., 176 F. Supp. 781, 783 (S.D.N.Y.), aff'd, 231 F.2d 843 (2d Cir.), cert. denied, 351 U.S. 972 (1956). Professor Loss has suggested that the section be amended to provide for enforcement by the SEC rather than the issuer and its security holders. 2 Loss 1053. Professor Cary, then chairman of the Commission, disagreed with this view on the grounds that the present system has been effective, that self-executing controls without governmental intervention should be preferred to procecdings by a regnlatory agency in behalf of private parties, and that the Commission does not have the manpower or financial resources to supervise and investigate so much private litigation. See Cary, Recent Developments in Securities Regulation, 63 Colum. L. REv. 856 (1963); Cary, Book Review, 75 HaRv. L. Rev. 857 (1962).

The argument that the government's role in private litigation should be minimized is countered by the assertion that such litigation is for a public purpose and, therefore, the public should be able to enforce its own interest. Munter, supra note 6, at 96-99. 
Rule 23 (b) of the Federal Rules of Civil Procedure, which requires that a plaintiff suing in a derivative capacity must have been a shareholder at the time of the transaction complained of or have received his shares by operation of law, has been found inapplicable to actions under section $16(\mathrm{~b}) .^{38}$

Although the corporation will not be liable for the attorney's fees incurred by a shareholder when there is no corporate recovery, ${ }^{39}$ any recovery resulting from enforcement by the corporation of a 16 (b) claim in response to the shareholder's demand may be reduced by the shareholder's attorney's fees. The courts have reasoned that effective enforcement of the statute requires the award of fees whether or not the shareholder is a party of record to the action..$^{40}$

Professor Loss has proposed that a percentage of any recovery arising out of action by the Commission should be awarded by the courts to the Federal Treasury. 2 Loss 1053-54. Although such allowances would be considerably less than the present allowances for plaintiffs' attorneys, this system of enforcement still retains the advantage of encouraging the corporation to act itself in order to avoid baving its recovery diminished. Id.

${ }^{38} 2$ Loss 1046. The courts have relied on the language and policy of $\$ 16(\mathrm{~b})$ to reach this conclusion. Dottenheim v. Murchison, 227 F.2d 737 (5th Cir.), cert. denied, 351 U.S. 919 (1955); Pellegrino v. Nesbit, 203 F.2d 463 (9th Cir. 1953). The statute states that suit may be brought by the owner of any security of the issuer without qualification. Moreover, "Congress did not intend procedural restrictions to hamper [a statutory policy intended to ultimately benefit the general public]. . . ." Benisch v. Cameron, 81 F. Supp. 882, 884 (S.D.N.Y. 1948). In the Murchison case the Fifth Circuit also indicated that the statute creates an entirely new cause of action and thus the shareholder's suit is not a derivative action which would be subject to the procedural requirements of Rule 23 (b). Dottenheim v. Murchison, supra at 738-39.

${ }^{30}$ Henss v. Schneider, 132 F. Supp. 60, 63 (S.D.N.X. 1955). Since the corporation's liability for fees is limited to payments out of the sum recovered, shareholder's counsel may also find that they have worked for little if the corporate recovery is small. See, e.gv Steinberg v. Sharpe, 95 F. Supp. 32, 34 (S.D.N.Y. 1950).

${ }^{10}$ Dottenheim v. Emerson Elec. Mfg. Co., 7 F.R.D. 195 (E.D.N.Y. 1947); Angoff v. Goldfine, 270 F.2d 185, 190 (1st Cir. 1959) (dictum); Henss v. Schneider, 132 F. Supp. 60, 63 (S.D.N.Y. 1955) (dictum). In sustaining the shareholder's complaint in Dottenheim, the court observed that to permit reimbursement only when an action had been brought and the expenses of legal proceedings had been incurred "would be penalizing efficiency and expediency." Dottenheim v. Emerson Elec. Mfg. Co., supra at 197.

Attorney's fees were subsequently awarded in Dottenheim even though the information contained in the demand letter was already known to the directors of the corporation. Dottenheim v. Emerson Elec. Mfg. Co., 77 F. Supp. 306 (E.D.N.Y. 1948). However, the approach of the court in determining the size of the fee may indicate a reluctance to grant allowances in such cases. The figure was reached in the following manner: since the corporation was aware of all the facts set forth in the demand letter, the letter merely "acted as a spur" to the corporation to demand payment from the insider. Id. at 307. After receiving this Ietter on December 17, 1945, the corporation requested and received from the insider on Febrnary 15, 1946, without any action being commenced, the sum of $\$ 57,872$. However, the statute of limitations would have given the corporation two years from the date on which the profit was 
The primary cases involving a claim for payment of fees although the shareholder never instituted suit have, however, limited the circumstances under which such awards will be made.

In Gilson v. Chock Full o' Nuts Corporation, ${ }^{41}$ the Second Circuit granted recovery of attorney's fees even though the shareholder was not a party of record to the action on the ground that his attorney had rendered substantial legal services beyond the mere preparation of the statutory request to sue.42 The court noted that the corporation, in response to the attorney's letter, advised the attorney that preliminary investigation had not revealed any violations of section 16 (b) by the accused insiders. The attorney, confronted with this negative attitude and the imminent running of the statute of limitations, then began to prepare a complaint which he planned to file shortly after expiration of the sixty-day period. On the sixtieth day, two days before the running of the statute, the shareholder's counsel was notified by the corporation that it had commenced an action that day against the insiders. Thus, since the attorney did more than merely find a claim and bring it to the corporation's attention, the court did not have to determine if counsel fees would have been recoverable for these limited services. While expressly refusing to decide this question, the court strongly intimated that compensation for finding a 16 (b) claim would be refused in the absence of the performance of additional and substantial professional services which might be justified by a negative response to the demand and the imminent running of the statute of limitations. ${ }^{43}$

realized, December 18, 1944, to institute the action. "Hence at most the contribution of the plaintiff was to enable the corporation without suit to have the use of $\$ 57,872$ from February 15, 1946, until December 18, 1946, a matter of ten months. Assuming that the corporation could have invested that sum at $4 \%,[i t] \ldots$ would have earned interest amounting to $\$ 1,929.05 . " I d$. at 307-08.

11331 F.2d 107 (2d Cir. 1964).

4 The district court had dismissed the complaint for failure to state a claim on the grounds that there was no allegation of an express contract of hire between the attoruey and the corporation and that legal fees should not be awarded on the basis of "[t]he mere sending of a letter and the investigation preliminary to it ...." Gilson v. Chock Full o'Nuts Corp., 224 F. Supp. 234, 236 (S.D.N.Y. 1963). A three judge panel of the Court of Appeals for the Second Circuit reversed the lower court, basing its decision on "[t]he principle of the Dottenheim case, [which], so far as we are informed, has never been questioned." 326 F.2d 246, 248 (2d Cir. 1964). See note 40 supra. In a rehearing en banc, the Second Circuit affirmed its reversal of the lower court. 331 F.2d 107 (2d Cir. 1964).

18 The court cited two cases, neither involving $\$ 16(\mathrm{~b})$, in which shareholders had been denied reimbursement for bringing to the corporation's attention a claim that it successfully prosecuted. $331 \mathrm{~F} .2 \mathrm{~d}$ at 109; see Evans v. Diamond Alkali Co., 315 
A New York district court, in Blau v. Rayette-Faberge, Incorporated ${ }^{44}$ met directly the issue of the effect of the Gilson dictum on recovery of fees for an investigation by a shareholder's attorney which yielded no more than a revelation of the existence of a potential 16(b) claim. While recognizing that extensive investigation had preceded preparation of the claim letter, the court concluded that the research had "no legal force ... since it related only to plaintiffs' efforts to bring to the attention of the corporation the transactions complained of." 45 Though plaintiff in this case had drafted a complaint, the court found this service to be prematurely rendered since, unlike in Gilson, the corporation expressed no reluctance to pursue the claim and the statute of limitations was not in danger of expiring.

If these opinions are accepted as sufficiently precedential, an affirmative response by the corporation to the shareholder's 16 (b) request is desirable. Presumably, either settlement or initiation of litigation is acceptable. Thus, despite the liberal judicial tendencies in rewarding the shareholder's attorney out of a corporate recovery, appropriate managerial action can avoid the detriment attendant this procedure.

The practical effect of the Gilson and Rayette decisions may be to thwart prompt enforcement of section 16 (b). The shareholder's attorney may not bring the claim to the attention of the issuer at the time the information is discovered. Rather, in order to increase the likelihood of recovery for filing a claim, he will delay his demand until after it becomes apparent that the corporation is not going to institute the action. Similarly, the attorney may withhold the demand until the two-year statute of limitations is about to run, thus reducing the sixty-day period permitted for corporate action. The corporation also may be encouraged to sit on the claim since it

Pa. 335, 172 A. 678 (1934); Ripley v. International Rys. of Cent. America, 227 N.Y.S.2d 64 (App. Div.), aff'd, 12 N.Y.2d 814, 187 N.E.2d 131, 236 N.Y.S.2d 64 (1962). The Second Gircuit added that: "Acts of this sort seem rather analogous to those of the informer, which, like those of other volunteers, are not usually compensable in the absence of statute. ... There are policy considerations against requiring a corporation to pay a stockholder for volunteering to do what the corporation ought to do and might well have done without any impulse from him, considerations that would be especially strong in a case where the stockholder's request was made shortly after the information became available from reports under $\$ 16(a)$ and at a time when the corporation still had many months in which to sue." 331 F.2d at 109.

$\$ 270$ F. Supp. 886 (S.D.N.X. 1967).

to Id. at 887 . 
probably will not be liable for any attorney's expenses until after demand has been made.

Legal Consideration: Liability of Corporate Officials for Breach of Fiduciary Duty.

Although there has not been extensive litigation on the question, ${ }^{46}$ possible breach of fiduciary duty implications exist in connection with corporate executives' failure to take proper action when a probable $16(\mathrm{~b})$ violation comes to their attention. ${ }^{47}$ The legal basis for dereliction of duty charges in this context is that Congress has vested the corporation with a statutorily-created cause of action which constitutes a corporate asset, ${ }^{48}$ and pursuing a course of action or inaction which intentionally or negligently causes the corporation to "waste" or diminish that asset constitutes a violation of the duty of fiduciary obligation which an officer or director owes to the

${ }^{16}$ Apparently, only one $\$ 16(\mathrm{~b})$ case, Truncale v. Universal Pictures Co., $76 \mathrm{~F}$. Supp. 465 (S.D.N.Y. 1948), specifically dealing with breach of fiduciary duty has been litigated. In the Truncale case the complaint alleged that the issuer's directors had violated their fiduciary obligations to the corporation by failing to act upon their knowledge that an officer had realized short-swing trading profits. More particularly, the directors were charged with conspiring to allow the two-year statute of limitations under $\$ 16(\mathrm{~b})$ to run, thus permitting waste of a corporate asset. Damages asked were in the amount of the officer's profits, for that was the value of the corporate asset allegedly wasted. The court lield that the "stockholder's claim under $\$ 16(\mathrm{~b})$ is not, strictly speaking, derivative at all, but one possessing independent statutory origin." Id. at 470 . Since the shareholder had an independent claim against the profiting officer, the court reasoned, New York law required a showing that the directors had by means of fraud or negligent misrepresentation contributed "to [the] inaction of the stockholders in the enforcement of their statutory cause of action. ..." Id. Since allegations of such conduct by the directors were not made, the complaint was dismissed with leave to amend. The court intimated that a different result would follow "[i]f the complaint alleged that the defendants had been guilty of deceit in iuducing stockholders to stay their hand, or had practiced a fraud upon the stockholders which lulled them into inaction, or, perhaps, had negligently made representations the proximate consequence of which was stockholder inaction ...." Id. at 470.71 .

ir Corporate counsel have apparently assumed that corporate officials have no affirmative duty to prevent $\$ 16$ (b) transactions or to discover them once they have occurred. An argument can be made, however, that the strong public policy in favor of enforcing the statutory provision and the peculiar need of assistance from corporate officials to accomplish this policy impose a duty upon directors to seek out $\$ 16$ (b) transactions. In terms of corporation law such a duty would be grounded on the doctrine that dixectors must exercise ordinary and reasonable supervision in conducting the affairs of the issuer. See Lowell Hoit \& Co. v. Detig, 320 Ill. App. 179, 50 N.E.2d 602 (1943); Graham v. Allis-Chalmers Mfg. Co., 41 Del. Ch. 78, 188 A.2d 125 (1963) (dictum).

${ }^{18}$ Truncale v. Universal Pictures Co., 76 F. Supp. 465 (S.D.N.Y. 1948); cf. United Copper Sec. Co. v. Amalgamated Copper Co., 244 U.S. 261 (1917); Koral v. Savory, Inc., 276 N.Y. 215, 11 N.E.2d 883 (1937). 
corporation. ${ }^{49}$ Although the right of the corporation to recover the short-swing profits is created by section $16(\mathrm{~b})$, local law determines whether corporate officials have breached their fiduciary duty to the issuer by preventing realization, or full realization, of the value of its claim.50 An action for damages is unlike other corporate assets, ${ }^{51}$ however, and a 16 (b) claim differs greatly from other causes of action that a corporation may have. ${ }^{52}$ By enacting the statute in the form it did, Congress established a unique private enforcement system to enforce a public law. Although the recovery of the shortswing profits inures to the benefit of the corporation, the exaction from the wrongdoing insider is not primarily for the protection of the issuer but for that of the mvesting public. ${ }^{53}$ Thus, the policy of the law necessarily must strongly favor the bringing of $16(\mathrm{~b})$ actions and oppose anything which impedes operation of the legislatively established enforcement system. What effect this consideration has on the standard that corporate officials must meet when investigating and prosecuting an alleged section $16(\mathrm{~b})$ violationand, more generally, to what extent the established common law governing corporate officals' fiduciary duty in other contexts is applicable in connection with section 16 (b)-is not yet clear. Courts recognize the uniqueness of a derivative action under section $16(\mathrm{~b})$, but they have not clearly established what standard will be applied to determine if corporate officials have violated their fiduciary obligation to the issuer.

When a possible insider short-swing transaction comes to the attention of the directors of the issuer, they will be called upon to make a business decision as to the course of action which the corpo-

10 See Harris v. Pearsall, 116 Misc. 366, 190 N.Y.S. 61 (Sup. Ct. 1921); cf. Isaac v. Marcus, 258 N.Y. 257, 179 N.E. 487 (1932); Moore v. Keystone Macaroni Mfg. Co., $370 \mathrm{~Pa} .172,87$ A.2d 295 (1952).

${ }^{20}$ Truncale v. Universal Pictures Co., 76 F. Supp. 465, 470 (S.D.N.Y. 1948).

¿1 "Wasting" a cause of action is more easily justified than is destroying tangible corporate property, for the directors can frequently rely on business justifications which militate against pursuing the cause of action in the public sphere.

t2 Normally when a corporation has a cause of action, the law is primarily concerned with restoring to the corporation what it rightly deserves. This is not so with $\$ 16(b)$, however, for its foremost purpose is to make the use of inside information unprofitable and the fact that the corporation is given a claim against the insider is only ancillary to accomplishment of the primary purpose. See note 3 supra and accompanying text.

Es See Smolowe v. Delendo Corp., 136 F.2d 231, 235 (2d Cir.), cert. denied, 320 U.S. 751 (1943); Marquette Cement Mfg. Co. v. Andreas, 239 F. Supp. 962, 965 (S.D.N.Y. 1965). 
ration will pursue. A rule of law, often referred to as the Business Judgment Rule, exists in most states whereby courts refuse to interfere in the internal affairs of a corporation as long as the directors are exercising their honest business judgment in making management decisions. ${ }^{54}$ Application of this Rule extends to decisions by directors concerning corporate causes of action.55 Generally what action a corporation shall take on a claim it may have is properly reserved to the discretion of its directors in the absence of instruction by vote from the shareholders. ${ }^{56}$ Courts normally will not interfere with the exercise of such discretion ${ }^{57}$ or permit a shareholder to question the considered decision of the directors by maintaining a derivative suit to enforce a right that belongs to the corporation. ${ }^{58}$ That privilege is vested solely in the corporation, acting through its directors, ${ }^{50}$ and mere failure on the part of the board to commence action does not entitle a shareholder to sue derivatively to compel realization of the corporate claim. ${ }^{60}$ In short, "a corporation's right not to sue is correlative to its right to sue." 61

At common law and under Rule 23(b) of the Federal Rules of Civil Procedure a shareholder bringing such an action must allege

54 See, e.g., Bennett v. Propp, 41 Del. Ch. 14, 187 A.2d 405 (1962); Taylor v. AxtonFisher Tobacco Co., 295 Ky. 226, 173 S.W.2d 377 (1943); Blaustein v. Pan Am. Petroleum \& Transp. Co., 293 N.Y. 281, 56 N.E.2d 705 (1944).

s5 See, e.g., United Copper Sec. Co. v. Amalgamated Copper Co., 244 U.S. 261 (1917); System Meat Co. v. Stewart, 175 Neb. 387, 122 N.W.2d 1 (1963).

vo See, e.g., Koral v. Savory, Inc., 276 N.Y. 215, 217, 11 N.E.2d 883, 884.85 (1937).

${ }^{57}$ See, e.g., United Copper Sec. Co. v. Amalgamated Copper Co., 244 U.S. 261, 264 (1917); Koral v. Savory, Inc., 276 N.Y. 215, 217, 11 N.E.2d 883, 885 (1937).

cs See, e.g., Goodwin v. Castleton, 19 Wash. 2d 748, 764, 144 P.2d 725, 731 (1944).

so See, e.g., Swanson v. Traer, 249 F.2d 854, 859 (7th Cir. 1957); Goodwin v. Castleton, 19 Wash. 2d 748, 764-65, 144 P.2d 725, 732 (1944).

${ }^{\circ 0}$ See, e.g., Swanson v. Traer, 249 F.2d 854, 859 (7th Cir. 1957).

${ }^{\circ 1} I d$. "As a general proposition, it is not doubted that directors or stockholders, as a matter of business policy, may refuse to bring a suit." S. Solomont \& Sons Trust, Inc. v. New England Theatres Operating Corp., 326 Mass. 99, 113, 93 N.E.2d 241, 248 (1950). In this same case the court said that if an "independent, disinterested majority of the stockholders acting reasonably and in good faith have voted that in their judgment it is not in the best interest of the corporation . . . ." to institute suit, a shareholder's derivative action to enforce the claim on behalf of the corporation would be dismissed. Id. at 114, 93 N.E.2d at 249 .

Apphication of these statements in the context of actions for insider short-swing trading is doubtful; for a refusal by the directors, acting in good faith, to pursue a $\$ 16$ (b) claim will not preclude a shareholder derivative action against the insider to prosecute the cause of action, see, e.g., Berkwich v. Mencher, 239 F. Supp. 792 (S.D.N.Y. 1965), and even approval of or encouragement to enter into the $\$ 16(\mathrm{~b})$ trans. action by the corporation will not bar such a derivative suit, see, e.g., Perfect Photo, Inc. v. Grabb, 205 F. Supp. 569 (E.D. Pa. 1962); Perlman v. Timberlake, 172 F. Supp. 246 (S.D.N.Y. 1959). 
that he has unsuccessfully exhausted his intracorporate remedies or explain why demand upon corporate officials to prosecute the claim would be futile. ${ }^{62}$ Failure to do so will preclude maintenance of his suit on behalf of the corporation. ${ }^{63}$ Furthermore, even if he fulfills this requirement by alleging existence of facts entitling him to sue derivatively, the propriety of the action or the necessity for its continued maintenance does not automatically follow. ${ }^{04}$ "The right of a stockholder of a corporation to bring suit to enforce, for the benefit of the corporation, a cause of action, which belongs to the corporation, is purely equitable."65 Moreover, in order to overcome the effect of the Business Judgment Rule, the shareholder, since he is relying on principles of equity, must allege and prove facts constituting an equitable basis permitting his intervention ${ }^{66}$-facts evidencing fraud, bad faith, breach of trust, gross mismanagement, ultra vires acts, ${ }^{67}$ or existence of a dual relation preventing an unprejudicial exercise of judgment ${ }^{68}$ on the part of the directors in determining either not to pursue or to compromise the claim.

Thus in practice it would seem that the Business Judgment Rule would act both to insulate the directors from liability for breach of fiduciary duty and to preclude a shareholder from maintaining a derivative action against the insider-trader if the directors have compromised the claim or determined not to pursue it. Generally courts will consider themselves lacking in sufficient expertise to review the reasonableness of such business judgments made by experienced corporate officials. ${ }^{69}$ However, one case, Pellegrino $v$.

${ }^{02}$ See, e.g., Wathen v. Jackson Oil \& Ref. Co., 235 U.S. 635, 639 (1915); DePinto v. Provident Security Life Ins. Co., 323 F.2d 826, 829 (9th Cir. 1963), cert. denied, 376 U.S. 950 (1964); Waller v. Waller, I87 Md. 185, 192, 49 A.2d 449, 453 (1946) (dictum).

${ }^{\circ} 3$ See, e.g., Wathen v. Jackson Oil \& Ref. Co., 235 U.S. 635 (1915); Swanson v. Traer, 249 F.2d 854 (7th Cir. 1957).

- See, e.g., Goodwin v. Castleton, 19 Wash. 2d 748, 762-63, 144 P.2d 725, 732 (1944).

of Koral v. Savory, Inc., 276 N.Y. 215, 218, 11 N.E.2d 883, 885 (1937).

${ }^{60}$ See, e.g., Swanson v. Traer, 249 F.2d 854, 859 (7th Cir. 1958); Koral v. Savory, Inc., 276 N.Y. 215, 218, 11 N.E.2d 883, 885 (1937); Goodwin v. Castleton, 19 Wash. 2d 748, 763-64, 144 P.2d 725, 732 (1944) ("The lone stockholder or the stockholders bringing such action not only have the burden of proving the material charges entitling the corporation itself to recover, but they must also establish the grounds entitling them to sue in place of the corporation.").

${ }^{\circ}$ See, e.g., Leggett v. Missouxi State Life Ins. Co., 342 S.W.2d 833, 850-51 (Mo. 1961).

${ }^{\circ}$ See, e.g., United Copper Sec. Co. v. Amalgamated Copper Co., 244 U.S. 261, 264 (1917); Koral v. Savory, Inc., 276 N.Y. 215, 218-19, 11 N.E.2d 883, 885 (1937); Isaac v. Marcus, 258 N.Y. 257, 264, 179 N.E. 487,489 (1932).

${ }^{\circ 0}$ See, e.g., Ingwersen Mfg. Co. v. Maddocks, 118 Colo. 281, 298-99, 195 P.2d 730, 739 (1948). 
Nesbit, ${ }^{70}$ has indicated that the strength of the rule may be diluted in the context of section 16(b). Implicitly acknowledging the "general rule that a corporation's board of directors may, subject to the exercise of good faith and a reasonable business judgment, determine whether the best interests of the corporation and its stockholders would be served by engaging in litigation," 11 the court held that section 16 (b) imposes "limitations" upon this usual discretion vested in the directors and, more specifically, that a decision by them not to appeal an adverse $16(\mathrm{~b})$ judgment does not preclude intervention by a shareholder to perfect an appeal from such judgment, ${ }^{72}$ even though the shareholder had not been a party to the original action. ${ }^{73}$ It is arguable, however, that the court meant to weaken the import of the Business Judgment Rule only when enforcement of $16(\mathrm{~b})$ is at issue, for it emphasized that "[a]ny stockholder has a right to institute suit if the corporation fails to do so, regardless of the good faith or reasonable business judgment of the board of directors." ${ }^{\prime 4}$ If this interpretation is correct, the permissible dis-

${ }^{70} 203$ F.2d 463 (9th Cir. 1953).

${ }^{71}, \mathrm{Id}$. at 466.67 .

72 Id. at $468-69$.

${ }^{73}$ Id. at 465 .

${ }^{74}$ Id. at 467 (emphasis added). On superficial analysis $\$ 16(\mathrm{~b})$ appears not to alter the common law doctrine permitting a shareholder to maintain a derivative action to enforce a corporate claim if the corporation's directors fail to prosecute its cause of action. See text following note 61 supra. Seemingly, the statute merely sets forth the shareholder's right in detail in the $\$ 16(\mathrm{~b})$ setting and regulates it procedurally by providing a notice requirement and waiting period-a built-in test to insure exhaustion of intracorporate remedies before resorting to the derivative action. Upon further study, however, it seems clear that $\$ 16(\mathrm{~b})$ modified the substance of a shareholder's right to question the directors' business decision not to pursue or to settle an insider trading claim. Under $\$ 16(\mathrm{~b})$ only the procedural regulations prescribed by the statute must be met, and the intervenor need not affirmatively establish an cquitable basis for his intervention, as is necessary in the usual derivative action to prosecute a corporate claim. See note 72 supra and accompanying text. Good faith inaction or compromise for an amount less than the insider's profits may insulate the directors from personal liability but will not necessarily preclude a shareholder derivative action against the insider. See notes $20-23$ supra and accompanying text.

It is this divergence from the general law governing derivative actions that prompted the Smolowe court to observe that $\$ 16(\mathrm{~b})$ "in effect creates a derivative right of action in every stockholder," 136 F.2d at 241, and the Truncale court to assert that a "stockholder's claim under $\$ 16$ (b) is not, strictly speaking, derivative at all, but one possessing independent statutory origin." $76 \mathrm{~F}$. Supp. at 470 . Sce note 61 supra. Unfortunately, lowever, the court in Truncale did not consider what effect, if any, this modification of the requirements to maintain an action on behalf of a corporation to enforce a corporate claim has on the standard of fiduciary obligation which officers and directors owe to the issuer. Unless public policy imposes a dual fiduciary duty on corporate officials, they should be answerable in terms of personal liability to the corporation and its shareholders only for failure to exercise im. 
cretion exercisable by the directors will be diminished when invocation of the Rule to preclude shareholders from prosecuting the claim would thwart the congressionally established enforcement procedure of section $16(\mathrm{~b})$. For purposes of defending against a derivative action alleging breach of fiduciary duty, however, the directors would still be permitted to rely on the fact that they acted in good faith and exercised their reasonable judgment in refusing to bring suit or in settling for a lesser amount than the alleged profits under section 16 (b). This distinction seems justified, for it is based on the assumption that the allegation of breach of fiduciary duty concerns only a duty owed to the corporation and not one owed to the public at large. Even though Congress has prescribed the unique enforcement measures under section $16(\mathrm{~b})$, it has not attempted an alteration of the standard of obligation owed to the issuer; and the shareholder's derivative action, alleging breach of duty, relates only to the relationship between the corporate principal and its officers and directors.

This distinction and the different purposes for which the Rule is being used can be illustrated by a simple example. Suppose that an alleged 16 (b) violation in which liability is clear is compromised by the board for an amount considerably less than the profit realized by the insider. Positing that the negotiations were at arm's length and that the directors acted in good faith and out of concern for such factors as injurious publicity and litigation expenses off-setting the financial gain from disgorgement, the Business Judgment Rule should protect them against charges of breach of fiduciary duty. However, consistent with the Pellegrino language that "limitations" upon the discretion normally vested in the directors exist in the context of section 16 (b), ${ }^{75}$ the settlement would not necessarily bar a shareholder derivative action against the insider for recovery of the difference between his profits under section $16(\mathrm{~b})$ and the negotiated amount of settlement. ${ }^{76}$ In permitting such an action, the

partially and in good faith their reasonable business judgment. Otherwise, in situations in which business considerations clearly dictate that they should not attempt to recover the short-swing profits of an insider, they will be subject to personal liability for breach of fiduciary duty for acting in the best interests of the corporation.

${ }^{70}$ See note 72 supra and accompanying text.

${ }^{70}$ It is unclear what will be in issue when a shareholder brings an action questioning the validity of a compromise. The fact that it is permissible for the corporation to consider the probability of recovery if it were to bring an action, see Lewis v. Rosenberg, [1957-1961 Transfer Binder] CCF FED. SEc. L. REP. If 90,856 (S.D.N.Y. 
court's concern would not be focused on the nature of the settlement between the insider and the corporation but upon "punishing" the insider for indulging in short-swing trading in the issuer's securities, a course of conduct which has been legislatively declared to be reprehensible to the public interest. ${ }^{77}$

The Business Judgment Rule will not always insulate the directors from personal liability, since if corporate officials abuse their discretion to control the issuer's business practices and thereby cause it to lose its claim against the insider, they will, under common law principles, be guilty of "waste" of a corporate asset and thus of breach of fiduciary duty owed to the corporation. ${ }^{78}$ For example, if the directors learn about possible insider short-swing activity and fail to take any action, not only are they thwarting operation of the statutory enforcement procedure, but they are also being negligent in their capacity as fiduciary representatives of the corporation. ${ }^{70}$

1955), indicates that only the good-faith nature of the settlement should be in issuc. Thus, even though a settlement is for an amount substantially less than the alleged profits realized by the insider, it should be approved by the court and should bar a shareholder's action against the insider. Nevertheless, because of the unique enforcement system under $\$ 16(\mathrm{~b})$, indications exist that a good-faith compromise will not always preclude further action by a security holder against the insider on behalf of the issuer. See notes 72, 74 supra and accompanying text.

${ }^{77}$ In permitting the shareholder to intervene in the issuer's suit against the insider, the Pellegrino court recognized the "punitive" aspect of $\$ 16(\mathrm{~b})$ and the often unrealistic nature of an action by the corporation against an insider by asserting that "once it [the issuer] commences litigation, the company's duty is not merely to determine diligently whether prosecution of the suit should continue, but, rather, the company has a duty diligently to prosecute the suit. A realistic approach to $\$ 16(\mathrm{~b})$ litigation requires recognition that a corporation will generally be reluctant to bring suit against its own beneficial owners, directors or officers." Pellegrino v. Nesbit, 203 F.2d 463, 467 (9th Cir. 1953).

is See note 46 supra.

${ }^{78}$ The court in Truncale indicated that more than inaction on the part of the directors would be needed before they would be subject to personal liability. Sce note 46 supra. However, this conclusion is subject to attack. Although the language of $\$ 16$ (b) eliminates the necessity of a shareholder establishing an equitable basis upon which to sue derivatively for the corporation, see note 74 supra and accompanying text, nothing contained in the provision alters the substance of what action or inaction by the directors will constitute a breach of fiduciary obligation to the issuer, id. Therefore, if under local law mere failure to act in the context of other claims which the corporation might have would lead to personal liability for the directors, such precedent should govern when a $\$ 16(\mathrm{~b})$ claim is in issue. Moreover, failure to pursue a corporate claim when insufficient reasons weigh against prosecution does constitute a breach of fiduciary duty in some jurisdictions. See, e.g., Harris v.

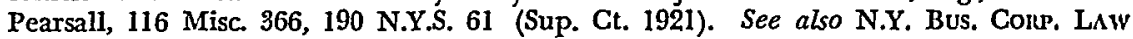
$\$ 720$ (a) (1) (A) (McKinney 1963), which provides: "An action may be brought against one or more directors or officers of a corporation to procure a judgment for the following relief: (1) To compel the defendant to account for his official conduct in the following cases: (A) The neglect of, or failure to perform, or other violation of his 
They would seemingly at least owe a duty to the issuer and its shareholders to investigate the claim and confront the insider with the allegation. If the board chooses to do nothing, running of the two-year statute of limitations under section 16 (b) will not insulate the individual directors from liability; for their breach occurs only at the time of the running of the statute of limitations on the 16 (b) claim, that is, when no action has been taken and action thereafter, due to their negligence, would be barred.

Finally, personal liability may attach to directors in situations in which the liability of the insider is relatively clear, and a suit by a shareholder to prosecute the claim on behalf of the corporation is imminent, if the directors fail to take any action. If they refuse to settle with the insider or to institute proceedings against him and the shareholder subsequently recovers the insider's profits for the benefit of the corporation, the directors arguably have breached their fiduciary duty by permitting "waste" of the claim to the extent the corporate recovery is reduced by payment of attorney's fees to the shareholder's lawyer. The alleged breach would not be of the duty to prosecute the claim in order to realize the corporate asset; rather, it would be for failing to prosecute when it was readily apparent that if they did not, the shareholder's attorney would commence a derivative action, thereby diminishing the recovery that the corporation would realize. ${ }^{80}$

\section{ConcLusion}

The considerations denominated "tactical" above gain legal siguificance insofar as they affect the reasonableness of a managerial judgment not to litigate or settle a section 16 (b) claim. However, an overriding factor may be the existence of the statutorily-granted remedy resting in most shareholders. Thus, not only does this provision secure an independent action for the shareholder, but it may also dilute the relevance of the Business Judgment Rule in the 16 (b) context. More important, perhaps, are the practical considerations flowing from the possibility of a suit for breach of duty for failure to consummate a 16 (b) claim. For instance, the disenchanted shareholder gains a statute of limitations in addition to

duties in the management and disposition of corporate assets committed to his charge."

${ }^{80}$ See notes 32.34 supra and accompanying text. 
that provided under the Securities Exchange Act. Further, a group of shareholders can have a broad selection of forums in both the state and federal jurisdictions. If this analysis establishes one lesson unequivocally, it is that with appropriate reactions the issuer can preclude applicability of any procedure which frustrates managerial control of the settlement of litigation.

G.R.M.

L.L.S. 